\title{
OCEANOGRAPHICAL PATTERNS DURING A SUMMER UPWELLING- DOWNWELLING EVENT IN THE NORTHERN GALICIAN RIAS. COMPARISON WITH THE WHOLE RIA SYSTEM (NW of Iberian Peninsula)
}

\author{
N. Ospina-Álvarez¹, R. Prego ${ }^{1}$, I. Álvarez ${ }^{2}$, M. deCastro², M.T. Álvarez-Ossorio ${ }^{3}$, Y. \\ Pazos $^{4}$, M.J. Campos ${ }^{3}$, P. Bernárdez ${ }^{1}$, C. García-Soto ${ }^{5}$, M. Gómez-Gesteira ${ }^{2}$ and \\ M. Varela ${ }^{3}$

\footnotetext{
${ }^{1}$ Marine Research Institute (IIM-CSIC). 36208, Vigo-Spain.

2 Environmental Physics Laboratory (EPhysLab). Faculty of Sciences (University of Vigo). 32004, Ourense-Spain.

${ }^{3}$ Oceanographic Center of A Coruña (IEO). 15001, A Coruña-Spain.

${ }^{4}$ INTECMAR (Xunta de Galicia). 36611, Vilagarcia de Arosa, Spain

${ }^{5}$ Oceanographic Center of Santander (IEO). 39004, Santander-Spain.
}

Corresponding author: Instituto de Investigaciones Marinas (IIM -CSIC). Eduardo Cabello, 6. 36208. Vigo, Spain. Tel. (+34) 986231930 ext. 140. E-mail: ospina@iim.csic.es

\begin{abstract}
Summer upwelling and downwelling processes were characterized in the Northern Galician Rias during July and August 2008 by means of sampling carried out onboard R/V Mytilus (CSIC) and R/V Lura (IEO). Thermohaline variables, dissolved oxygen, nutrients, chlorophyll, phytoplankton, ciliates and zooplankton abundances were measured at sections located in the Rias of Viveiro, Barqueiro and Ortigueira and their adjacent shelves. Ekman transport was calculated from QuikSCAT satellite, upwelling intensity estimated with upwelling index from the average daily geostrophic winds, and SST maps obtained from NASA GHRSST satellite. Ekman transport and SST behaviour showed two different patterns: (i) offshore and upwelling favourable conditions on $13-22^{\text {nd }}$ of July; (ii) onshore and downwelling favourable conditions from $23^{\text {rd }}$ July to $19^{\text {th }}$ August). During upwelling, TS diagram showed an intrusion of Eastern North Atlantic Central Water affecting the continental shelf but not the rias. Nutrient salt concentrations increased with depth, reaching their maximum values near the mouth of Ortigueira Ria. During downwelling, coastal water increased its temperature $\left(18.5-19.8^{\circ} \mathrm{C}\right)$ and was retained inside rias; nutrients were nearly depleted, except for the innermost ria (estuarine zone) due to fluvial nutrient inputs. In this inner area, the maximum of chlorophyll-a (Barqueiro Ria) was observed. Low phytoplankton abundances were measured in both cases, even though a short increase in the plankton biomass was observed inside rias during upwelling, while under downwelling a small red tide of Lingulodinium polyedrum was detected. During the upwelling period Northern Rias tend to be mesotrophic systems as revealed by nutrient concentrations, chlorophyll levels and plankton abundances. On the contrary, in similar situations, the Western Rias behaves as eutrophics.

In the Northern Galician shelf, the average of upwelling (downwelling) was $1.9 \pm 0.8$ $(2.1 \pm 1.0)$ events $\cdot \mathrm{yr}^{-1}$ from May to September (1990-2008) considering at least one week with favourable wind conditions and $U \mathrm{U}$ averages out of the range of \pm 500 $\mathrm{m}^{3} \cdot \mathrm{s}^{-1} \cdot \mathrm{km}^{-1}$.
\end{abstract}


Keywords: thermohaline variables; nutrient salts; chlorophyll; plankton; ciliates;Galician rias .

\section{INTRODUCTION}

Coastal upwelling is one of the main factors controlling the circulation in the upper layers of the ocean waters (Fraga, 1981). During upwelling events, colder and saltier waters from deeper layers, inject nutrients into the illuminated surface layers, favouring phytoplankton growth (Wooster and Reid, 1963). Due to the high productivity of these world regions they are profusely researched (Cushing, 1969). This is the case of the Current System of California (Bograd et al, 2009; Hickey and Royer, 2008), Peru-Humboldt (Silva et al. 2009; Karstensen and Ulloa, 2008), Canaries (Barton, 2008; Pastor et al. 2008) and Benguela (Burls and Reason, 2008; Shannon, 2009). In the North Atlantic Ocean, the Eastern North Atlantic Upwelling System extends from the south of Dakar at $10^{\circ} \mathrm{N}$ to the tip of the Iberian Peninsula at $44^{\circ} \mathrm{N}$ (Wooster et al., 1976). Its upper boundary is in the Galician coast where upwelling of Eastern North Atlantic Central Water (ENACW), located between 70-500 m depth, usually occurs during spring and summer (Fraga, 1981; Rios et al., 1992). ENACW upwelling intensifies between the Cape Finisterre and Punta Rocundo $\left(42^{\circ} 52^{\prime}-43^{\circ} 17^{\prime} \mathrm{N}\right)$ and high concentrations of nitrate can be detected along the upwelling core in the Western Rias coast (Fraga, 1981; Prego et al., 1999a). Galicia which is situated in the north-western corner of the lberian Peninsula, has three different littoral orientations. This fact makes the effect of northerly prevailing wind conditions (Torres et al., 2003; Alvarez et al., 2005a; Gómez-Gesteira et al., 2006) on upwelling development to be different both in probability and intensity at north of Cape Ortegal, where are the Northern Rias, between Capes Ortegal and Finisterre, where are the Middle Rias, and south of Cape Finisterre, where are the Western Rias (Figure 1).

Upwelling events in the Western Rias have been intensively studied from hydrographical (Fraga, 1981; Alvarez-Salgado et al., 1993; Prego et al., 2001; Herrera et al., 2008) and biogeochemical (Tenore et al., 1982; Blanton et al., 1984; Prego et al., 1995; Alvarez-Salgado et al., 1996; Bernárdez et al., 2006) points of view. The relationship between upwelling and thermohaline variables has been studied extensively in the western Galician coast (Nogueira et al., 1997; Pardo, 2001; Torres, 2003; Dale et al., 2004; Alvarez et al., 2005b) because the emergence of low temperature and high salinity in the surface and subsurface waters (Hu et al., 2001) is a good indicator of upwelling. In contrast with upwelling events south of Finisterre which are more intense and closer to the coast, upwelling events in the Northern Rias is discontinuous and remains mainly near the edge of the continental shelf (Prego and Bao, 1997). Upwelling in the Middle Rias of Artabro Gulf, is characterized by the no entrance of ENACW into the rias, while the opposite occurs in the Western Rias where ENACW upwells inside them (Prego and Varela, 1998).

In contrast with the Western Galician Rias, Northern Galician Rias has been scarcely investigated existing some researches focused on biological (Sánchez et al., 1998) and sedimentary aspects (Otero et al., 2000; Lorenzo, 2007). Upwellingdownwelling studies have not been extensively undertaken in this northern Galician zone, excepting some recent researches. Gonzalez-Pola et al. (2005) studied an early spring pulse of downwelling observed in the western Cantabrian 
shelf-slope; Alvarez et al. (2009) analyzed the evidence of a winter upwelling event in the northern Rias. The upwelled seawater inside the estuaries has a shelf bottom origin and it is not associated with Eastern North Atlantic Central Water or the Iberian Poleward Current as observed in the Western Rias (deCastro et al., 2006; Prego et al., 2007; deCastro et al., 2008); Alvarez et al. (2010) analyzed summer upwelling frequency along the Cantabrian Coast from 1967 to 2007 and monitored sea temperature related to wind forcing in the Barqueiro Ria.

The hydrographical, biogeochemical, plankton pattern and frequency of summer upwelling events for the Northern Rias remains still unknown. Moreover, donwelling episodes have not been described, such as in the Western Rias (deCastro et al., 2004; Torres and Barton, 2007). These episodes could be associated with red tides episodes (Fraga et al., 1988; Prego, 1992; Tilstone et al., 1994) that were not yet reported for the Northern Rias.

According to the wind patterns and coastal orientation, it may be hypothesise that the upwelling events in the Northern Rias and neighbouring shelf must be different to that of the rest of Galician rias. In this way, physical, chemical and biological, data were obtained in favourable and unfavourable upwelling conditions in July-August 2008. Therefore, the aims of this article are: (i) to characterize a summer both, upwelling and downwelling events in the Northern Galician Rias; (ii) to analyze the frequency of meteorological conditions favourable to upwelling and donwelling events in the northern coast of Galicia; (iii) to compare the oceanographic patterns of the current Northern Rias case with the existing information about the Middle and Western Rias.

\section{MATERIALS AND METHODS}

\subsection{Study area}

The northernmost point of the Iberian Peninsula, Cape Estaca de Bares $\left(43^{\circ} 47.5^{\prime} \mathrm{N}\right)$, is located in the western coast of the Cantabrian Sea. In this area, there are three Galician Rias (Figure 1): Ortigueira (38 $\mathrm{km}^{2}$ of surface), Barqueiro $\left(10 \mathrm{~km}^{2}\right)$ and Viveiro $\left(27 \mathrm{~km}^{2}\right)$. They form a whole named as 'Northern Galician Rias' or 'Rias Altas', according to the tectonic classification proposed by Torre Enciso (1958). This ria classification is also in accordance with the own hydrological pattern of the rivers running into the Northern Rias. At the innermost area, these Rias receive the fluvial discharges of the Mera, Sor and Landro Rivers (annual average flows of $4.2,6.0$ and $7.1 \mathrm{~m}^{3} \cdot \mathrm{s}^{-1}$, respectively; Río-Barja and Rodríguez-Lestegás, 1992). These flows are low compared with the fluvial contributions in the Western Galician Rias (Muros, Arosa, Pontevedra and Vigo) where the annual average river discharge ranges from 17 to $79 \mathrm{~m}^{3} \cdot \mathrm{s}^{-1}$. Therefore, marine processes mainly control the hydrodynamics of the Northern Rias, except at the innermost estuarine zone (mesotidal: tidal range of 2-4 $\mathrm{m}$ ), which is partially enclosed with well-developed beach barriers (Lorenzo et al., 2007). For this reason the Northern Rias can be considered as funnel-like incised valleys characteristic of a relatively submerged coastline (Evans and Prego, 2003) with 30-35 m depth at their open mouths to the north swell. In this geographical area, climate is wet temperate oceanic (Cfb Köppen type), with an annual average of temperature of $13.1^{\circ} \mathrm{C}$, ranging from $8^{\circ} \mathrm{C}$ in winter to $18^{\circ} \mathrm{C}$ in summer, and 1370 $\mathrm{mm}$ of precipitation with 130 days of rain per year. 


\subsection{Hydrographical and chemical water column sampling}

Two cruises were conducted on board the RV Mytilus and RV Lura to investigate the oceanographic characteristics in the water column of the Northern Galician Rias during an upwelling and downwelling processes. The first cruise was carried out on July $16-17^{\text {th }}$ after one week of upwelling favouring prevailing winds, and the second on August $19-20^{\text {th }}$ during the upwelling relaxation phase, which started on $23^{\text {rd }}$ July and dominated by western winds. Eighteen seawater stations were visited in the Rias of Ortigueira, Barqueiro and Viveiro (Figure 1). Six stations at different depths, between 10 and $100 \mathrm{~m}$, were studied in every ria during July and seven stations during August. Vertical profiles of temperature and salinity were measured with a Seabird-9/11plus CTD placed in a SeaBird-32 Rosette (RV Mytilus) and a CTD SeaBird-25 with PAR and Fluorescence sensors placed in a General Oceanic Mini-Rosette (RV Lura). Water samples at each station were collected at standard depths $(0,5,10,20,40,60,80$ and $90 \mathrm{~m})$ using General Oceanic Niskin bottles of 5-L (RV Lura) or 12-L (RV Mytilus), for chemical and biological sub-sampling. Dissolved oxygen concentrations were measured the next sampling day by Winkler titration of samples to calculate saturation percentages (Aminot, 1983). Nutrient salts were frozen onboard at $-20^{\circ} \mathrm{C}$ and later analyzed in the laboratory using an Integral Futura autoanalyzer system (Alliance Instruments) with separate lines to nitrate, nitrite, ammonium, phosphate and silicate according to standard colorimetric methods (Hansen and Koroleff, 1999). Samples for analysis of chlorophyll-a were immediately filtered through a Whatman GF/F filter (25 mm diameter) and chlorophyll concentration was determinate by spectrofluorimetry (Neveux and Panouse, 1987) after extraction with $90 \%$ acetone according to the method described by UNESCO (1994).

\subsection{Biological water column sampling}

Particulate organic carbon and nitrogen (POC and PON, respectively) and plankton abundances of different groups were measured at station 5 ( $20 \mathrm{~m}$ depth) located in the middle of the channel of the Barqueiro Ria. To determine POC and PON water aliquots were filtered through glass microfiber filters (Whatman GF/F, $25 \mathrm{~mm}$ diameter) using a FlashEA 11-12 Termoquesth $\mathrm{CNH}$ analyzer; in the case of POC, carbonate was not removed from the filters, as the contribution of carbonate to total carbon represents only up to $2 \%$ of total paticulate carbon (Fernández et al., 1995, Palanques et al., 2002). Samples for quantification of phytoplankton were preserved in Lugol's solution to be examined under a Nikon Eclipse TE 300 inverted microscope, following the technique described by Utermöhl (1958). The used nomenclature was based on Tomas (1997).

Planktonic ciliates were sampled and identified using a protocol similar to the one described for phytoplankton. Samples were sedimented during 48 hours in $100 \mathrm{ml}$ chambers. Taxonomic classification was based on Lynn and Small (2002) criteria. The counting of individuals was performed at $200 x$ magnification.

Samples of microzooplankton $(40-200 \mu \mathrm{m})$ were collected with vertical hauls, of a $20 \mathrm{~cm}$ diameter bongo-type net of $40 \mu \mathrm{m}$ mesh size, and filtering codends was used. Samples were screened through $40 \mu \mathrm{m}$ nylon mesh and fixed in $2 \%$ borate-buffered formalin before microscope examination. Taxonomic classification of species was based on Valdés et al. (1991) criteria. 
Mesozooplankton samples were collected by oblique hauls a Juday-Bogorov net with $200 \mu \mathrm{m}$ mesh size (50 cm diameter) and equipped with flow and depth meters (Bode et al. 1998). Samples were fixed in $4 \%$ formalin before microscope analysis.

\subsection{Hydrological and hydrochemical sampling of rivers}

Daily river flow data of the main rivers running into the three Northern Rias during July and August were supplied by the 'Aguas de Galicia' company dependent on the 'Consellería de Medio Ambiente' of the 'Xunta de Galicia'. The flows were area corrected considering the whole river basin area: 270, 202 and $127 \mathrm{~km}^{2}$ of Landro, Sor and Mera Rivers, respectively. These three rivers were sampled four times near their mouth: $2^{\text {nd }}, 15^{\text {th }}$ and $30^{\text {th }}$ July and $18^{\text {th }}$ August. Salinity was verified using a WTW MultiLine F/Set-3 (error range: \pm 0.1 ). Dissolved oxygen concentrations were measured at the next sampling day by Winkler titration of samples to calculate saturation percentages (Aminot, 1983), with an error range of \pm 0.2 . Nutrient salts samples (nitrate, nitrite, ammonium and phosphate) were collected in $50 \mathrm{~mL}$ plastic bottles and immediately frozen at $-20^{\circ} \mathrm{C}$; then they follow the previously cited procedure used for the seawater nutrient samples. As orthosilicate polymerization may occur in freshwater frozen samples (Kobayashi, 1966), rivers were also sampled using $10 \mathrm{~mL}$ plastic bottles and preserved at $4^{\circ} \mathrm{C}$ and dissolved silicate was analyzed next day. The accuracy of the analytical procedure was assessed by the analysis of certified reference materials: MOOS-1 (seawater nutrients; NRC, Canada), obtaining good agreement with the certified values. The precision as relative standard deviation (RSD) was always less than $5 \%$. Samples for chlorophyll-a analysis were also taken and processed as the seawater samples.

\subsection{Satellite and Meteorological data}

Maps of Sea Surface Temperature (SST) have been elaborated using the NASA GHRSST satellite data base that combines measurements of several thermal infrared (AVHRR, MODIS, AATSR and SEVIRI) and microwave (AMSR-E and TMI) satellite sensors. The data set has a precision of $0.1 \mathrm{~K}$, a spatial resolution of $5 \mathrm{~km}$ and a daily temporal resolution. Details of the processing at NASA-JPL can be found at ftp://podaac.jpl.nasa.gov/GHRSST/doc/GHRSST_guide_doc.pdf.

Surface wind fields from July to August 2008 were provided by the QuikSCAT satellite, and retrieved from the Jet Propulsion Laboratory web site (http://podaac.jpl.nasa.gov/quikscat/ qscat_data.html). The data set consists of global grid values of meridional and zonal components of wind measured twice daily on an approximately $0.25^{\circ} \times 0.25^{\circ}$ grid with global coverage. QuikSCAT data are given in an ascending and descending pass. Data corresponding to one pass present numerous shadow areas, therefore, an average between both passes was considered to increase the coverage. It is necessary to take into account that wind data close to coast $(\sim 25 \mathrm{~km})$ are not available due to the existence of a small coast mask, nevertheless, a statistical comparison between QuikSCAT wind measurements and high resolution numerical models was carried out along the Galician coast (Penabad et al., 2008), revealing similar results between models and satellite data. Ekman transport was calculated using the wind speed from the 
QuikSCAT satellite at 5 control points located along the northern Galician coast at latitude $44.25^{\circ} \mathrm{N}$ and from $8.25^{\circ} \mathrm{W}$ to $7.25^{\circ} \mathrm{W}$ (Figure 1).

Ekman transport data provided by the Pacific Fisheries Environmental Laboratory (PFEL) (http://www.pfeg.noaa.gov) were considered from 1990 to 2008. The PFEL distributes environmental index products and time series data bases to cooperating researchers, taking advantage of its long association with the U.S. Navy's Fleet Numerical Meteorology and Oceanography Centre (FNMOC). For our purposes six-hourly Ekman transport data model derived from Sea Level Pressure were considered at a control point located at $43.5^{\circ} \mathrm{N}, 10.5^{\circ} \mathrm{W}$ (Figure 1 , gray square). Data were averaged to obtain daily series. Considering than UI can be defined as the Ekman transport component in the direction perpendicular to the shore-line (Nykjaer and Van Camp, 1994; Gomez-Gesteira et al. 2006), then the $Q_{y}$ component of the Ekman transport can be considered as the Ul for the Northern Galician Rias $\left(U I_{N}=+Q_{y}\right)$. Positive values of $U I\left(\mathrm{~km} \cdot \mathrm{m}^{-3} \cdot \mathrm{s}^{-1}\right)$ indicate upwelling-favourable conditions. Conversely, negative values indicate downwelling-favourable onshore Ekman transport. Along the western coast of the Iberian Peninsula (Western Rias), the northerly component of shelf wind-stress causes upwelling favourable conditions $\left(U I_{W}=-Q_{x}\right)$ with offshore Ekman transport (Wooster et al., 1976; Bakun and Nelson, 1991) and southerly winds result in the opposite effect.

\section{RESULTS}

\subsection{Meteorological situation and seawater transport}

Images of SST along the Northern Galician Rias each five days between July 12 and August 19 of 2008 are presented in Figure 2. This figure also shows the Ekman transport. At the beginning of July (days 8-12; Figure 2a) transport was mainly directed southeastward, i.e. upwelling unfavorable according to the coastline direction. Then, for the days previous to the cruise carried out in July (days 13-17, Figure 2b), the transport pattern varied; it was completely different pointing northwestward (upwelling favorable) along the coast and showing approximately the same direction and amplitude at each point. This situation remained during the very next days, (from July 18 to 22, Figure 2c), but the transport pattern changed again at the end of the month (days 23-27, Figure 2d) toward southeastward direction although with low intensity. This upwelling unfavorable behavior persisted (Figure 2e) and increased in August; transport was mainly directed southward (days 1-19, Figure 2f) showing the same direction and amplitude at each point resulting in downwelling favorable conditions.

\subsection{July Upwelling event}

The TS diagram of thermohaline data (Fig. 3) measured inshore (st.5, Fig.1) and offshore (st.8) of the three Rias under upwelling (July $17^{\text {th }}, 2008$ ) and downwelling (August 19 ${ }^{\text {th }}, 2008$ ) conditions (Fig. 2) shows the presence of a saltier and colder water mass associated with the ENACW during the favourable upwelling event of July. During July the main variables measured in the rivers are shown in Table 1. The flow of rivers ranged from 0.4 to $7.5 \mathrm{~m}^{3} \cdot \mathrm{s}^{-1}$ and temperature and dissolved oxygen saturation from 16.1 to $19.7^{\circ} \mathrm{C}$ and from 96 to $98 \%$, respectively. Concentration levels of nutrient salts were in the range of $32-50 \mu \mathrm{M}$ 
for nitrate, $0.1-0.2 \mu \mathrm{M}$ for nitrite, 0.2-4.0 $\mu \mathrm{M}$ for ammonium, 0.1-2.9 $\mu \mathrm{M}$ for phosphate and $99-215 \mu \mathrm{M}$ for silicate while the values for Chlorophyll-a ranged between 0.4-0.9 $\mathrm{\mu g} \cdot \mathrm{L}^{-1}$. Sor River is quasi-pristine.

In the rias and their neighbouring shelf, nutrient salts concentrations (Fig.4a and $4 b$ ) increased with depth, reaching their maximum concentrations near bed. Nitrate was practically depleted in the inner surface waters of Barqueiro and Viveiro Rias and the highest values were measured at bottom near the shelfbreak (in both rias: 9.2-9.5 $\mu \mathrm{M}$ nitrate). Ortigueira Ria presented a similar distribution pattern but without nutrient depletion, with values from 1 to $13 \mu \mathrm{M}$ nitrate as result of upwelling inputs and remineralisation processes in the shelf seawater column reflected by the high ammonium concentrations at mid seawater layers (up to 4.6 $\mu \mathrm{M}$, Fig.4b). Phosphate (0.0-0.6 $\mu \mathrm{M})$ and silicate $(0.7-5.1 \mu \mathrm{M})$ showed similar trends to those of nitrate in the three rias, however the highest concentrations were at the top of the innermost ria stations $(1.9 \mu \mathrm{M}$ of phosphate in Ortigueira Ria and $7.9 \mu \mathrm{M}$ of silicate in Barqueiro Ria). Dissolved oxygen was only measured in the Barqueiro Ria and showed a clear horizontal stratification (Fig.4a), with welloxygenated surface waters at surface $(102 \%)$ and decreased oxygen saturation at the bottom $(72 \%)$.

Chlorophyll-a was low ( 0.1 to $\left.0.7 \mu \mathrm{g} \cdot \mathrm{L}^{-1}\right)$ in the Barqueiro and Viveiro Rias, however an important increase up to $2.7 \mu \mathrm{g} \cdot \mathrm{L}^{-1}$ was observed in the Ortigueira Ria at st.6 and 7 with the highest concentration in the first 20 m (Fig.4a and 4b). Plankton abundances were quantified at st.5 in the Barquiero Ria (Fig.1). The mean abundances of phytoplankton (mean of four depths sampled; Table 2, July) were dominated by naked flagellates with mean abundances of 500 cells $\cdot \mathrm{mL}^{-1}$. Larger phytoplankton showed a predominance of diatoms, with 42 cells cells $\cdot \mathrm{mL}^{-1}$. Auxospores of Chaetoceros, Pseudo-nitzschia delicatissima, Guinardia delicatula, Leptocylindrus minimus and $L$. mediterraneus were the dominant species. Dinoflagellates were less abundant than diatoms (abundances of $11 \mathrm{cells} \cdot \mathrm{mL}^{-1}$ ). Amphidinium flagellans, Prorocentrum minimum, Heterocapsa niei and small species of Gymnodinium were the dominant taxa in July. Other groups displayed negligible abundances. Planktonic ciliates showed very low abundances, around 0.15 cells $\cdot \mathrm{mL}^{-1}$. Lohmaniella oviformis and Strombidium acutum were the dominant taxa (Table 2, July). Microzooplankton abundance in July was high, around 12000 indiv $\cdot \mathrm{m}^{-3}$, and dominated by larvae of copepods (nauplii), bivalves and gastropods. Mesozooplankton abundance was also high with values above $5000 \mathrm{indiv} \cdot \mathrm{m}^{-3}$, with copepods (mainly copepodits), and apendicularia as the dominant groups (Table 3, July).

\subsection{August Downwelling event}

Temperature and salinity on $19^{\text {th }}$ August 2008 at st.5 and 7 situated inside rias and in their neighbouring shelf respectively, displayed a little variability; they varied from 35.4 and $19.6^{\circ} \mathrm{C}$ near surface to 35.7 and $18.6^{\circ} \mathrm{C}$ near bed. The TS diagram showed a clear difference respect to the upwelling situation of July (Fig.3). Under these environmental conditions a depletion of nutrient salts was observed along the water column of the Barqueiro Ria (Fig.4a) and offshore seawaters. Maximum concentrations of nutrients were low close to the bottom: $1.4 \mu \mathrm{M}$ of nitrate, 0.16 $\mu \mathrm{M}$ of nitrite, $1.4 \mu \mathrm{M}$ of ammonium, $0.15 \mu \mathrm{M}$ of phosphate (at surface in the innermost ria station) and $3.5 \mu \mathrm{M}$ of silicate. The main nutrient source to this oldpoor seawater was the fluvial outputs. The Sor River on 18th August 2008 (Table 
1) contributed to the Barqueiro Ria with $0.25 \mathrm{molN} \cdot \mathrm{s}^{-1}$ (96\% as nitrate), 0.14 $\mathrm{mmolP} \cdot \mathrm{s}^{-1}, 0.64 \mathrm{molSi} \cdot \mathrm{s}^{-1}$, which was used by phytoplankton in the innermost ria zone where the highest concentration of chlorophyll-a was measured $\left(2.40 \mu \mathrm{g} \cdot \mathrm{L}^{-1}\right)$. There was a slightly increase of $\mathrm{POC}$ and $\mathrm{PON}$ concentration inside the Barqueiro Ria from July to August (St.5, from $920 \mathrm{mgC} \cdot \mathrm{m}^{-2}$ and $175 \mathrm{mgN} \cdot \mathrm{m}^{-2}$ to $1370 \mathrm{mgC} \cdot \mathrm{m}^{-}$ ${ }^{2}$ and $210 \mathrm{mgN} \cdot \mathrm{m}^{-2}$ ), similarly to $\mathrm{C}: \mathrm{N}(\mathrm{mol}: \mathrm{mol})$ ratio gone from 6.2 to 7.4 .

Mean abundances of phytoplankton measured in August throughout the water column (Table 2) revealed that small flagellates were, as in July, the most abundant component of phytoplankton, with abundances higher than 1000 cells $\cdot \mathrm{mL}^{-1}$. Phytoplankton species composition of larger phytoplankton showed a dominance of diatoms. Chaetoceros auxospores, Rhizosolenia and Thalassiosira species, displayed similar abundances as those of July, while $P$. delicatissima, $G$. delicatula, L. minimus and L. mediterraneus clearly decrease in August. Significant increase was observed for small Navicula species, Navicula transitans, Nitzschia longissima or Paralia sulcata. Dinoflagellates remained with in similar abundances, reaching around 10 cells $\cdot \mathrm{mL}^{-1}$. Dominant species in July, dropped their abundances in August, and the more salient peculiarity is the high increase of the red tide forming species Lingulodinium polyedrum (from $10 \%$ of total dinoflagellates in July to $76 \%$ in August, Table 2). In any case, low phytoplankton abundances were observed both, in July and August, in dinoflagellates and diatoms as well. Planktonic ciliates were slightly higher than in July, with abundances around 1 cells $\cdot \mathrm{mL}^{-1}$. The taxa present in July, increased their abundances and some other species appeared as dominant in this date. This is the case of Myrionecta rubra and Tontonia gracillima (Table 2), Microzooplankton abundance clearly decreased as compared to those of July, reaching around 6000 indiv $\cdot \mathrm{m}^{-3}$, with copepods nauplii larva as dominants, followed by bivalve larvae and some species of tintinnids (Table 3, August). Mesozooplankton also decreased with mean abundances about 3000 indiv $\cdot \mathrm{m}^{-3}$. Dominance shared among different groups, with copepods displaying higher densities, followed by apendicularia, cladocerans and bivalves larvae (Table 3, August).

\subsection{Wind-induced conditions in the Northern and Western coast of Galicia}

The upwelling phenomenon occurring in the areas close to northern and western coasts of Galicia can be compared from results shown in the Figure 5 . In this figure, values of daily upwelling index during the upwelling seasons from 1990 to 2008 calculated at the $43.5^{\circ} \mathrm{N}-10.5^{\circ} \mathrm{W}$ point were represented on an $U I_{W}$ versus $\mathrm{UI}_{\mathrm{N}}$ axes system. The northerly component of shelf wind-stress causes upwelling favourable conditions in the Western Galician coast $\left(U I_{W}=-Q_{x}\right)$ while the same occurs with the easterly component to the Northern coast. The figure corresponds to UI favourable in both coasts (positive $U I_{W}$ and $U I_{N}$ ). UI points situated inside the figure fit to the lineal regression $U I_{N} / U I_{W}=0.94$ indicating that the upwelling conditions were $6 \%$ higher in the western shelf.

\section{DISCUSSION}

The Ekman transport sequence in the western Cantabrian Sea (Fig.2), resulting from the wind pattern triggered the high pressures crossing on Galicia (Wooster et al., 1976; Fiuza et al., 1982; Torres and Barton, 2007; Alvarez et al., 
2008), suggests that the observed upwelling and downwelling events may be as usual in the northern Galician coast as in the Western Rias area during the upwelling season (Prego, 1992; Tilstone et al., 1994; Diz et al., 2006).

During the upwelling event, ENACW was detected on the shelf off the Northern Rias (from $65 \mathrm{~m}$ depth to the bottom, Fig.3). Upwelling did not reach the surface water, where high temperatures were observed, especially at the inshore stations. Both facts seems to be usual resulting a significant difference with respect to the rias located close (Varela et al., 2005) and south (Rosón et al., 1997; Prego et al., 2001) Cape Finisterre because upwelling penetrates inside them, raising up to surface layers (Alvarez-Salgado et al 1993; Alvarez et al., 2005a). Another difference is the origin of the upwelled water mass. Western of Cantabrian Sea is characterized by the presence of ENACW from sub-polar origin (ENACW $\left.{ }_{P}\right)($ Fraga, 1981; Llope et al., 2006) while in the event of July 2008 (Fig.3), the subtropical branch $\left(\mathrm{ENACW}_{\mathrm{T}}\right.$ ), formed along a front near the Azores (Fiuza et al., 1983; Rios et al., 1992), upwelled in the northern Galician coast, as it occurs in the Finisterre upwelling in the western coast (Blanton et al., 1984).

After the spring bloom of phytoplankton in the Western Rias the ENACW transport nutrient salts to the photic layer (Fraga 1981, Prego et al., 1999b) during the upwelling events turning these rias into eutrophic zones (Varela et al., 2008). This was not observed in the Northern Rias where low nitrate and chlorophyll concentrations were measured in the water column (Fig.4A). This highlights that upwelling did not affect these rias and they could be considered as mesotrophic systems. The innermost or estuarine ria zone may be an exception, even though this matter deserves more attention. However, the whole northern shelf was not evenly affected by the wind-induced upwelling. The Ortigueira zone was the most influenced with a significant vertical mixing in the lower layer of the water column, as shown by the TS diagram (Fig.3). The consequence is a higher input of nutrient salts to the photic layer, a subsequent phytoplankton growth and a remineralisation area marked both, by chlorophyll and ammonium maxima (Fig.4B). Nevertheless, this process occurs out the Ortigueira Ria but near its mouth. The Ortigueira case as compared to Barqueiro and Viveiro shelves could be only a consequence of the Cape Estaca de Bares effect because upwelling processes are more intense and persistent at southern areas of the capes (Crepon et al. 1984), as it was observed in the neighbouring Cape Peñas (Molina, 1972; Botas et al., 1990; Llope et al., 2006) and Cape Ajo (Lavín et al., 1998) in the central Cantabrian coast. On the other hand, in the Western Rias the remineralisation supplies recycled nutrients at the inner ria (Alvarez-Salgado et al., 1996; Prego, 2002), while in the Northern Rias this process is negligible.

During the downwelling event temperatures higher than those of upwelling were observed in the Northern Rias (Fig.3). Western winds moved the surface seawater coastward as indicated by the Ekman transport (Fig.2), a process similar to those observed in other Galician Rias (Cabanas and Alvarez, 2005). Waters were retained inside the rias, and nutrients were almost exhausted (Fig.4A). In these circumstances, river outflow might be the main nutrient source and consequently phytoplankton is constrained to the innermost ria zone as shown by the chlorophyll-a distribution. (Fig.4A). This can also explain the slightly increase of POC and PON concentration inside the Barqueiro Ria from July to August associated to a higher $\mathrm{C}: \mathrm{N}$ ratio as a consequence of an enhanced remineralisation related to downwelling. However, remineralisation in the Northern Rias was not as important as in Western Rias where high concentrations of 
recycled nutrients maintain a high biological activity (Alvarez-Salgado et al., 1996; Varela et al., 2004). In any case, low phytoplankton abundances were observed both, in July and August, although the enrichment of the water due to the upwelling may be reflected in an increase in the biomass of some species of phytoplankton and zooplankton (Tables 2 and 3), e.g Pseudo-nitzschia cf. delicatissim which abundance is associated with nitrate and nitrite concentrations (Kaczmarska et al. 2007, Loureiro, 2009). Other species of diatoms can be dominant in any season when silicate concentrations in water are greater than 2 $\mu \mathrm{M}$ (Egge and Aksnes 1992); this would explain why there are no great differences between the mean abundance of diatoms during July and August.

In the case under study at the northern shelf, there were nine days of upwelling favourable conditions previous to sampling, with average UI of 1095 $\mathrm{m}^{3} \cdot \mathrm{s}^{-1} \cdot \mathrm{km}^{-1}$. It occurred only ten times during the interval of 1990-2008. The poor intensity of upwelling events for the western Cantabrian coast was reported by Alvarez et al. (2010) who estimated a probability of around $17 \%$ for upwelling favourable conditions of at least five days from June to September. The downwelling occurred in northern region after seven days with an average UI of $660 \mathrm{~m}^{3} \cdot \mathrm{s}^{-1} \cdot \mathrm{km}^{-1}$. The events in the Northern coast can be characterized by defining conditions to favourable upwelling $\left(+U I_{N}\right)$ and downwelling $\left(-U I_{N}\right)$ periods: at least one week with averages out of the range of $\pm 500 \mathrm{~m}^{3} \cdot \mathrm{s}^{-1} \cdot \mathrm{km}^{-1}$. Under these conditions, the average of upwelling events per year was $1.9 \pm 0.8$ from May to September during the studied period of nineteen years with an average of $12 \pm 4$ days of easterly winds and UI of $870 \pm 270 \mathrm{~m}^{3} \cdot \mathrm{s}^{-1} \cdot \mathrm{km}^{-1}$ Nevertheless, in 1997 not events were observed. The wind-forcing pattern in the Northern coast of Galicia is $6 \%$ less favourable to upwelling (75\% of events) than in the Western zone (Fig.5). The difference between the two Galician regions increases when the lasting and intensity of the upwelling process are considered. UI values (up to $1390 \pm 180 \mathrm{~m}^{3} \cdot \mathrm{s}$ ${ }^{1} \cdot \mathrm{km}^{-1}$; Alvarez et al., 2005a) and event time scale (10-15 days; Nogueira et al., 1997) are higher in the western shelf.

The frequency of downwelling was $2.1 \pm 1.0$ event $\cdot \mathrm{yr}^{-1}(13 \pm 7$ days of westerly winds and $760 \pm 200 \mathrm{~m}^{3} \cdot \mathrm{s}^{-1} \cdot \mathrm{km}^{-1}$ ) with no cases in 1990, four in 1999 and three events higher than $-1000 \mathrm{~m}^{3} \cdot \mathrm{s}^{-1} \cdot \mathrm{km}^{-1}$ in the whole period. From May to September, downwelling was like upwelling-events in frequency. Downwelling was lower in intensity but they can last larger than upwelling. There were only six chained upwelling-downwelling transitions, including the one studied, during the period 1990-2008. This scarcity in upwelling-relaxations processes could explain why, red tides events were not yet reported for the Northern Rias while they are a typical event during downwelling in the Western Rias (Figueiras et al., 1994). In any case, the August downwelling was associated to a small red tide of Lingulodinium polyedrum which dominated the dinoflagellates community (Table 2).

\section{CONCLUSIONS}

The classical topics related to oceanographic patterns of Galician Rias are mainly derived from the initial studies carried out about upwelling and downwelling in the Western Rias. However, these topics need to be revised after the first results obtained in the Northern Galician Rias. In this northern coastline under wind induced upwelling conditions during summer, the upwelling remained out of rias affecting only the neighbouring shelf such as Prego and Bao (1997) forecasted. Therefore, in that time period Northern Rias tend to be mesotrophic 
systems as indicated by nutrient and chlorophyll concentrations as well as plankton abundances. On the contrary, under the same conditions, the Western Rias tend towards eutrophy. A different shoreline direction seems to play a significant role in the hydrographical, biogeochemical and biological patterns during upwelling and donwnwelling events. More research should be undertaken at the boundaries of the upwelling systems, such as that in northern Galicia $\left(43^{\circ} \mathrm{N}\right)$ respect to the eastern boundary of the central North Atlantic upwelling system $\left(43^{\circ}-10^{\circ} \mathrm{N}\right)$.

On the other hand, there are explicit geologic-tectonic (Torre-Enciso, 1958) and implicit climatological-hydrological reasons (Soto and Díaz-Fierros, 1996) to classify the Galician Rias in three categories: Northern, Middle and Western Rias. The present study carried out in the Northern Rias, gives oceanographical reasons to validate the above mentioned classification.

Acknowledgements. Authors thank the crew of the R/V Mytilus (CSIC) and R/V Lura (IEO) for their kind assistance during field work; Mrs. V. Prieto of the 'Delegación Territorial de Lugo de la Consellería do Mar (Xunta de Galicia)' for laboratory facilities in Celeiro Harbour; 'Aguas de Galicia' for the river flows; Dr. M. Cabanas for the UI data; A. Rodríguez-Riveiros and J. Lorenzo for their technical assistance in the analysis and data processing. M.Sc. N. Ospina-Alvarez thanks CSIC for her pre-doctoral JAE contract. This article is a contribution to the Spanish LOICZ program and was supported by the project 'Influence of meteorological forcing, land geochemistry and estuarine zone in the hydrodynamic, biogeochemical cycle of trace metal and rare earth and plankton transport in the Northern Galician Rias (NW Spain)' financed by CICYT, ref. CTM2007-62546C03/MAR (Acronym: INTERESANTE).

\section{References}

Alvarez, I., Gómez-Gesteira, M., deCastro, M., Prego, R., 2005a. Variation in upwelling intensity along the NorthWest Iberian Península (Galicia). J. Atmos. Ocean. Sci. 10, 309-324.

Alvarez, I., deCastro, M., Gómez-Gesteira, M., Prego, R., 2005b. Inter- and intraannual analysis of the salinity and temperature evolution in the Galician Rias Baixas-ocean boundary (Northwest Spain). J Geophys Res. 110, C04008.

Alvarez, I., Gómez-Gesteira, M., deCastro, M., Novoa, E. M., 2008. Ekman transport along the Galician Coast (NW, Spain) calculated from QuikSCAT winds. J. Mar. Syst. 72, 101-115.

Alvarez, I., Ospina-Alvarez, N., Pazos, Y., deCastro, M., Bernardez, P., Campor, M. J., Gómez-Gesteira, J. L., Alvarez-Ossorio, M. T., Gómez-Gesteira, M., Varela, M., Prego, R., 2009. A winter upwelling event in the Northern Galician Rias: frequency and oceanographic implications. Estuar. Coast. Shelf Sci. 82, 573-582.

Alvarez, I., Gómez-Gesteira, M., deCastro, M., Gómez-Gesteira, J. L., Dias, J. M., 2010. Summer upwelling frequency along the western Cantabrian coast from 1967 to 2007 . J. Mar. Syst. 79, 218-226 
Alvarez-Salgado, X. A., Roson, G., Perez, F. F., Pazos, Y., 1993. Hydrographic variability off the Rias Baixas (NW Spain) during the upwelling season. J. Geophys. Res. 98, 14447-14455.

Alvarez-Salgado, X. A., Rosón, G., Pérez, F. F., Figueiras, F. G., Pazos, Y., 1996. Nitrogen cycling in an estuarine upwelling system, the Ria de Arousa (NW Spain). I. Short-time-scale patterns of hydrodynamic and biogeochemical circulation. Mar. Ecol. Prog. Ser. 135, 259-273.

Aminot, A., 1983. Dosage de l'oxygène dissous, in: Aminot, A., Chaussepied, M. (Eds.), Manuel des Analysses Chimiques en Milieu Marin. CNEXO, Brest, pp. 75-92.

Bakun, A., Nelson, C. S., 1991. Wind stress curl in subtropical eastern boundary current regions. J. Phys. Oceanogr. 21, 1815-1834.

Barton, E. D., 2008. Ocean Currents: Atlantic Eastern Boundary, Canary Current Portugal Current, in: Steele, J.H., Turekian, K.K., Thorpe, S.A. (Eds.), Encyclopedia of Ocean Sciences. Academic Press, London, pp. 380-389

Bernárdez, P., Francés, G., Prego, R., 2006. Benthic-pelagic coupling and postdepositional processes as revealed by the distribution of opal in sediments: the case of the Ría de Vigo (NW Iberian Peninsula). Estuar. Coast. Shelf Sci. 68, 271-281.

Blanton, J. O., Atkinson, L. P., Castillejo, F., Montero, A. L., 1984. Coastal upwelling of the Rias Bajas, Galicia, northwest Spain, Hydrographic studies. Rapp. P.V. Reun. Cons. Int. Explor. Mer. 183, 79-90.

Bode, A., Álvarez-Ossorio, M. T., González, N., 1998. Short communication: Estimations of mesozooplankton biomass in a coastal upwelling area off NW Spain. J. Plankton Res. 20, 1005-1014.

Bograd, S. J., Schroeder, I., Sarkar, N., Qiu, X., Sydeman, W. J., Schwing, F. B., 2009. Phenology of coastal upwelling in the California Current. Geophys. Res. Lett. 36, L01602.

Botas, J., Fernandez, E., Bode, A., Anadon, R., 1990. A persistent upwelling off the Central Cantabrian Coast (Bay of Biscay). Estuar. Coast. Shelf Sci. 30, 185-199.

Burls, N., Reason, C. J. C., 2008. Modelling the sensitivity of coastal winds over the Southern Benguela upwelling system to different SST forcing. J. Mar. Syst. 74, 561-584.

Cabanas, J. M., Alvarez, I., 2005. Ekman transport patterns in the area close to the Galician coast (NW, Spain). J. Atmos. Ocean. Sci. 14, 325-341.

Crepon, M., Richez, C., Chartier, M., 1984. Effects of coastline geometry on upwellings. J. Phys. Oceanogr. 14, 1365- 1382.

Cushing, D. H., 1969. Upwelling and fish production. FAO Fisheries Technical Paper. 84, 1-40.

Dale, A. W., Prego, R., Millward, G. E., Gómez-Gesteira, M., 2004. Transient oceanic and tidal contributions to water exchange and residence times in a coastal upwelling system in the NE Atlantic: the Pontevedra Ria, Galicia. Mar. Pollut. Bull. 49, 235-248.

deCastro, M., Gómez-Gesteira, M., Prego, R., Taboada, J. J., Montero, P., HerBello, P., Perez-Villar, V., 2000. Wind and Tidal Influence on Water Circulation in a Galician ria (NW Spain). Estuar. Coast. Shelf Sci. 51, 161176. 
deCastro, M., Gómez-Gesteira, M., Alvarez, I., Prego, R., 2004. Negative estuarine circulation in the Ria of Pontevedra (NW Spain). Estuar. Coast. Shelf Sci. 60, 301-312.

deCastro, M., Dale, A. W., Gómez-Gesteira, M., Prego, R., Alvarez, I., 2006. Hydrographic and atmospheric analysis of an autumnal upwelling event in the Ria of Vigo (NW Iberian Peninsula). Estuar. Coast. Shelf Sci. 68, 529537.

deCastro, M., Gómez-Gesteira, M., Alvarez, I., Lorenzo, M., Cabanas, J. M., Prego, R., Crespo, A. J. C., 2008. Characterization of fall-winter upwelling recurrence along the Galician western coast (NW Spain) from 2000 to 2005: Dependence on atmospheric forcing. J. Mar. Syst. 72, 145-158.

Diz, P., Frances, G., Roson, G., 2006. Effects of contrasting upwellingdownwelling on benthic foraminiferal distribution in the Ria de Vigo (NW Spain). J. Mar. Syst. 60, 1-19.

Egge, J. K., Aksnes, D. L., 1992. Silicate as regulating nutrient in phytoplankton competition. Mar. Ecol. Prog. Ser. 83, 281-289.

Evans, G., Prego, R., 2003. Rias, estuaries and incised valleys: Is a ria an estuary? Mar. Geol. 196, 171-175.

Fernandez, E., Maranon, E., Cabal, J., Alvarez, F., Anadon, R., 1995. Vertical particle flux in outer shelf waters of the southern Bay of Biscay in summer 1993. Oceanol. Acta. 18, 379-384.

Figueiras, F. G., Jones, K. J., Mosquera, A. M., Álvarez-Salgado, X. A., Edwards, A., MacDougall, N., 1994. Red tide assemblage formation in an estuarine upwelling ecosystem: Ria de Vigo. J. Plankton Res. 16, 857-878.

Fiúza, A., 1983. Upwelling patterns off Portugal, in: Suess, E., Thi, J. (Eds.), Coastal Upwelling, its sediment record. Part A. Responses of the sedimentary regime to present coastal upwelling. Plenum, New York pp. 85-98.

Fiúza, A., Macedo, M. E., Guerreiro, M. R., 1982. Climatological space and time variation of the Portuguese coastal upwelling. Oceanol. Acta. 5, 31-40.

Fraga, F., 1981. Upwelling off the Galician Coast, Northwest Spain, in: Richards, F.A. (Ed.), Coastal Upwelling. AGU, Washington, pp. 176-182.

Fraga, S., Anderson, D. M., Bravo, I., Reguera, B., Steindinger, K. A., Yentsch, C. M., 1988. Influence of upwelling relaxation on dinoflagellates and shellfish toxicity in the Ria de Vigo, Spain. Estuar. Coast. Shelf Sci. 27, 349-361.

Gómez-Gesteira, M., Moreira, C., Alvarez, I., de Castro, M., 2006. Ekman transport along the Galician coast (northwest Spain) calculated from forecasted winds. J. Geophys. Res. C Oceans. 111, C10005.

Gonzalez-Pola, C., Ruiz-Villarreal, M., Lavin, A., Cabanas, J. M., Alvarez-Fanjul, E., 2005. A subtropical water intrusion spring-event in the shelf-slope of the south-western Bay of Biscay after strong wind-forcing pulses. J. Atmos. Ocean. Sci. 10, 343-359.

Hansen, H. P., Koroleff, F., 1999. Determination of nutrients, in: Grasshoff, K., Kremling, K., Ehrhardt, M. (Eds.), Methods of Seawater Analysis. WileyVCH Verlag, Weinheim, pp. 159-226.

Herrera, J. L., Rosón, G., Varela, R. A., Piedracoba, S., 2008. Variability of the western Galician upwelling system (NW Spain) during an intensively sampled annual cycle. An EOF analysis approach. J. Mar. Syst. 72, 200217. 
Hickey, B. M., Royer, T. C., 2008. California and Alaska Currents, in: Steele, J.H., Turekian, K.K., Thorpe, S.A. (Eds.), Encyclopedia of Ocean Sciences. Academic Press, London, pp. 368-379.

Hu, J. Y., Kawamura, H., Hong, H. S., Suetsugu, M., Lin, M. S., 2001. Hydrographic and satellite observations of summertime upwelling in the Taiwan strait: a preliminary description. Terr. Atmos. Ocean Sci. 12, 415430.

Kaczmarska, I., Martin, J., Ehrman, J., LeGresley, M., 2007. Pseudo-nitzschia species population dynamics in the Quoddy Region, Bay of Fundy. Harmful Algae. 6, 861-874.

Karstensen, J., Ulloa, O., 2008. Peru-Chile Current System, in: Steele, J.H., Turekian, K.K., Thorpe, S.A. (Eds.), Encyclopedia of Ocean Sciences. Academic Press, London, pp. 4240-4248.

Kobayashi, J., 1966. Silica in freshwater and estuaries, in: Golterman, H.L., Clymo, R.S. (Eds.), Chemical environment in the aquatic habitat. Biosphere Programme Symposium, Amsterdam, pp. 41-55.

Lavin, A., Valdés, L., Gil, J., Moral, M., 1998. Seasonal and inter-annual variability in properties of surface water off Santander, Bay of Biscay, 1991-1995. Oceanol. Acta. 21, 179-190.

Lavin, A., Díaz del Rio, G., Casas, G., Cabanas, J. M., 2000. Afloramiento en el noroeste de la Peninsula Iberica. Indices de afloramiento para el punto $43^{\circ}$ $\mathrm{N} 11^{\circ} \mathrm{W}$ periodo 1990-1999. Datos y Resúmenes. Instituto Español de Oceanografía. 15, 1-25.

Lorenzo, F., Alonso, A., Pagés, J. L., 2007. Erosion and accretion of beach and spit systems in northwest Spain: A response to human activity. J. Coast. Res. 23, 834-845.

Loureiro, S., Jauzein, C., Garcés, E., Collos, Y., Camp, J., Vaqué , D., 2009. The significance of organic nutrients to Pseudo-nitzschia delicatissima (Bacillariophyceae) nutrition. J. Plankton Res. 31, 399-410.

Lynn, D. H., Small, E. B., 2002. An Illustrated Guide to the Protozoa, in: Lee, J.J., Bradbury, P.C., Leedale, G.F. (Eds.), Phylum Ciliophora. Society of Protozoologists, Lawrence, Kansas., pp. 371-656.

Llope, M., Anadon, R., Viesca, L., Quevedo, M., Gonzalez-Quiros, R., Stenseth, N. C., 2006. Hydrography of the southern Bay of Biscay shelf-break region: integrating the multiscale physical variability over the period 1993-2003. J. Geophys. Res. 111, C09021.

Molina, R., 1972. Contribución al estudio del upwelling frente a la costa noroccidental de la Península Ibérica. Bol. IEO, 3-39.

Neveux, J., Panouse, M., 1987. Spectrofluorometric determination of chlorophylls and pheophytins. Archiv für Hydrobiologie. 109, 567-581.

Nogueira, E., Perez, F. F., Rios, A. F., 1997. Modelling thermohaline properties in an estuarine upwelling ecosystem (Ria of Vigo: NW Spain) using boxeJenkins transfer function models. Estuar. Coast. Shelf Sci. 44, 685702.

Nykjaer, L., Van Camp, L., 1994. Seasonal and Interannual variability of coastal upwelling along northwest Africa and Portugal from 1981 to 1991. J. Geophys. Res. 99, 14197-142070tero, X. L., Huerta-Diaz, M. A., Macias, F., 2000. Heavy metal geochemistry of saltmarsh soils from the Ria of Ortigueira (mafic and ultramafic areas, NW Iberian Peninsula). Environ. Pollut. 110, 285-296. 
Otero, X. L., Huerta-Diaz, M. A., Macias, F., 2000. Heavy metal geochemistry of saltmarsh soils from the Ria of Ortigueira (mafic and ultramafic areas, NW Iberian Peninsula). Environ. Pollut. 110, 285-296.

Palanques, A., Isla, E., Puig, P., Sanchez-Cabeza, J. A., Masqué, P., 2002. Annual evolution of downward particle fluxes in the Western Bransfield Strait (Antarctica) during the FRUELA project. Deep Sea Res. Part 2 Top Stud. Oceanogr. 49, 903-920.

Pardo, P. C., Gilcoto, M., Pérez, F. F., 2001. Short-time scale coupling between thermohaline and meteorological forcing in the Ria de Pontevedra. Sci. Mar. 65, 229-240.

Pastor, M. V., Pelegrí, J. L., Hernández-Guerra, A., Font, J., Salat, J., Emelianov, M., 2008. Water and nutrient fluxes off northwest Africa. Cont. Shelf Res. 28, 915-936.

Penabad, E., Alvarez, I., Balseiro, C. F., deCastro, M., Gómez, B., PerezMuñuzuri, V., Gómez-Gesteira, M., 2008. Comparative analysis between operational weather prediction models and QuikSCAT wind data near the Galician coast. J. Mar. Syst. 72, 256-270.

Prego, R., 1992. Flows and budgets of nutrient salts and organic carbon in relation to a red tide in the Ria of Vigo (NW Spain). Mar. Ecol. Prog. Ser. 79, 289302.

Prego, R., 2002. Nitrogen fluxes and budget seasonality in the Ria Vigo (NW Iberian Peninsula). Hydrobiologia. 475, 161.

Prego, R., Bao, R., 1997. Upwelling influence on the Galicia coast: silicate in shelf water and underlying surface sediments. Cont. Shelf Res. 17, 307-318.

Prego, R., Varela, M., 1998. Hydrography of the Artabro Gulf in summer: western coastal limit of Cantabrian seawater and wind-induced upwelling at Prior Cape. Oceanol. Acta. 21, 145.

Prego, R., Bao, R., Howland, R., 1995. The biogeochemical cycling of dissolved silicate in a Galician Ria. Ophelia. 42, 301-318.

Prego, R., Barciela, C., Varela, M., 1999a. Nutrient dynamics in the Galician coastal area (northwestern Iberian Peninsula): do the Rias Bajas receive more nutrient salts than the Rias Altas? Cont. Shelf Res. 19, 317.

Prego, R., Varela, M., Bode, A., Canle, M., Lorenzo, J., Carballo, R., 1999b. Oceanography of the Gulf of Artabro (nortwestern of Iberian Peninsula) in early spring: general patterns. Biol Inst Esp Oceanogr. 15, 73-79.

Prego, R., Dale, A. W., deCastro, M., Gómez-Gesteira, M., Taboada, J. J., Montero, P., Villareal, M. R., Perez-Villar, V., 2001. Hydrography of the Pontevedra Ria: Intra-annual spatial and temporal variability in a Galician coastal system (NW Spain). J. Geophys. Res. C Oceans. 106, 1984519857.

Prego, R., Guzman-Zuñiga, D., Varela, M., deCastro, M., Gómez-Gesteira, M., 2007. Consequences of winter upwelling events on biogeochemical and phytoplankton patterns in a western Galician ria (NW Iberian peninsula). Estuar. Coast. Shelf Sci. 409-422, 409.

Río-Barja, F. J., Rodríguez-Lestegás, F., 1992. Os ríos galegos. Consello da Cultura Galega, Santiago de Compostela.

Ríos, A. F., Pérez, F. F., Alvarez-Salgado, X. A., Figueiras, F. G., 1992. Water masses in the upper and middle North Atlantic Ocean east of the Azores. Deep-Sea Res. 39, 645-658. 
Rosón, G., Álvarez-Salgado, X. A., Pérez, F. F., 1997. A non-stationary box model to determine residual fluxes in a partially mixed estuary, based on both thermohaline properties: application to the Ría de Arousa (NW Spain). Estuar. Coast. Shelf Sci. 44, 249-262.

Sánchez, J. M., Otero, X. L., Izco, J., 1998. Relationships between vegetation and environmental characteristics in a salt-marsh system on the coast of Northwest Spain. Plant. Ecol. 136, 1-8.

Shannon, L. V., 2009. Benguela Current in: Steele, J.H., Turekian, K.K., Thorpe, S.A. (Eds.), Encyclopedia of Ocean Sciences. Academic Press, London, pp. $255-267$

Silva, N., Rojas, N., Fedele, A., 2009. Water masses in the Humboldt Current System: Properties, distribution, and the nitrate deficit as a chemical water mass tracer for Equatorial Subsurface Water off Chile. Deep Sea Res. Part 2 Top Stud. Oceanogr. 56, 1004-1020

Soto, B., Diaz-Fierros, F., 1996. As augas de Galicia balance hídrico, in: DiazFierros, F. (Ed.), As Augas de Galicia. Consello de Cultura Galega, Santiago de Compostela, pp. 107-146.

Tenore, K. R., Boyer, L. F., Cal, R. M., Corral, J., García-Fernández, C., González, N., González-Gurriaran, E., Hanson, R. B., Iglesias, J., Krom, M., LópezJamar, E., McClain, J., Pamatmat, M. M., Pérez, A., 1982. Coastal upwelling in the Rias Bajas, NW Spain: contrasting the benthic regimes of the Rias de Arosa and de Muros. J. Mar. Res. 40, 701-770.

Tilstone, G. H., Figueiras, F. G., Fraga, F., 1994. Upwelling-downwelling sequences in the generation of red tides in a coastal upwelling system. Mar. Ecol. Prog. Ser. 112, 241-253.

Tomas, C. R., 1997. Identifying marine phytoplankton. Academic Press, New Cork.

Torre-Enciso, E., 1958. Estado actual del conocimiento de las rías gallegas, in: Homaxe a R. Otero Pedrayo. Ed. Galaxia, Vigo, Spain., pp. 237-250.

Torres, R., Barton, E. D., 2007. Onset of the Iberian upwelling along the Galician coast. Continent. Shelf Res. 27, 1759-1778.

Torres, R., Barton, E. D., Miller, P., Fanjul, E., 2003. Spatial patterns of wind and sea surface temperature in the Galician upwelling region. J. Geophys. Res. 108 (C4), 3130.

UNESCO, 1994. Protocols for the joint global ocean flux study (JGOFS) core measurements, Manuals and guides 29. IOC-SCOR.

Utermöhl, H., 1958. Zur Vervollkommung der quantitativen phytoplanktonmethodik. Mitt. Int. Ver. Limnol. 9, 1-38.

Valdés, L., Alvarez-Ossorio, M. T., Lavín, A., Varela, M., Carballo, R., 1991. Ciclo anual de parámetros hidrográficos, nutrientes y plancton en la plataforma continental de La Coruña (NO, España). 7, 91-138.

Varela, M., Prego, R., Pazos, Y., 2004. Vertical biogenic particle flux in a western Galician ria (NW Iberian Peninsula). Mar. Ecol. Prog. Ser. 269, 17-32.

Varela, M., Prego, R., Pazos, Y., Moroño, A., 2005. Influence of upwelling and river runoff interaction on phytoplankton assemblages in a Middle Galician Ria and Comparison with northern and southern rias (NW Iberian Peninsula). Estuar. Coast. Shelf Sci. 64, 721-737.

Varela, M., Prego, R., Pazos, Y., 2008. Spatial and temporal variability of phytoplankton biomass, primary production and community structure in the 
Pontevedra Ria (NW Iberian Peninsula): oceanographic periods and possible response to environmental changes. Mar. Biol. 154, 483-499.

Wooster, W. S., Bakun, A., McLain, D. R., 1976. Seasonal upwelling cycle along the eastern boundary of the North Atlantic. J. Mar. Res. 34, 131-141.

Wooster, W. S., Reid Jr, J. L., 1963. Eastern Boundary Currents, in: Hill, M.N. (Ed.), The Sea. InterScience, New York, pp. 253-280. 


\section{Figure legends}

Figure 1. Map of Northern Galician Rias showing the sampling stations (black circles) of cruises carried out in July and August 2008. Asterisks in the upperright map represent the five control points considered to analyze wind data provided by the QuikSCAT satellite. Gray square on the map in the right corner correspond to the control point $\left(43.5^{\circ} \mathrm{N}, 10.5^{\circ} \mathrm{W}\right)$ for Ekman transport data considered from 1990 to 2008.

Figure 2. Temporal evolution of the Sea Surface Temperature (SST) maps and Ekman transport pattern (white arrows) along the northern Galician coast during the upwelling-downelling event. SST images correspond to the date shown on the lower-left corner of each frame. Ekman transport was calculated averaging the surface wind fields from QuikSCAT satellite data to the SST date and three previous days (lower-right corner of each frame).

Figure 3. TS diagram corresponding to the stations located at the mouth (St. 5) and at the continental shelf (July: St.8 and August: St.7) of the Ortigueira, Barqueiro and Viveiro Rias (see Fig.1). Grey band in the lower-right corner corresponds to the Eastern North Atlantic Central Water mass (ENACW).

Figure 4. Contour maps of nitrate, nitrite, ammonium and chlorophyll-a concentrations and dissolved oxygen saturation percentages along the main channel (sections in Fig.1) on July 17 for the three Northern Rias (A and B) and on August 19 to the Barqueiro Ria (A).

Figure 5. Daily upwelling index (UI) for the Northern Galician coast $\left(U I_{N}\right)$ vs. the Western Galician coast $\left(\mathrm{Ul}_{\mathrm{W}}\right)$ calculated at the control point $43.5^{\circ} \mathrm{N}, 10.5^{\circ} \mathrm{W}$. Data belong to the upwelling season (May-September) over the period of 1990-2008. Positive values of UI $\mathrm{W}_{\mathrm{W}}$ and $U \mathrm{I}_{\mathrm{N}}$ correspond with $\mathrm{UI}$ favourable conditions in both coasts. Straight line shows the linear fit (as $y=a x, p$-value $<0.001)$. The percentage of total data considered is also indicated. 
Table 1

Click here to download Table: Table_1.doc

Table 1. Master variables of the three main rivers flowing into the headwaters of the Northern Galician Rias. The measurements were made fortnightly during the months of the sea cruises.

\begin{tabular}{|c|c|c|c|c|c|c|}
\hline \multirow[b]{2}{*}{ River } & \multirow[b]{2}{*}{ Parameter } & \multicolumn{4}{|c|}{ Date } & \multirow[b]{2}{*}{ Unit } \\
\hline & & 2 July & 15 July & 30 July & 18 August & \\
\hline & Upwelling Index & -962 & 1421 & -813 & -713 & $\mathrm{~m}^{3} \cdot \mathrm{s}^{-1} \cdot \mathrm{km}^{-1}$ \\
\hline \multirow[t]{9}{*}{ Mera } & Flow & 1.49 & 1.19 & 0.40 & 0.71 & $\mathrm{~m}^{3} \cdot \mathrm{s}^{-1}$ \\
\hline & Temperature & 16.1 & 17.3 & 17.0 & 17.4 & ${ }^{\circ} \mathrm{C}$ \\
\hline & Dissolved oxygen saturation & - & 97.5 & - & 95.5 & $\%$ \\
\hline & Nitrate & 49.8 & 46.9 & 49.4 & 57.8 & $\mu \mathrm{M}$ \\
\hline & Nitrite & 0.15 & 0.24 & 0.17 & 0.33 & $\mu \mathrm{M}$ \\
\hline & Ammonium & 0.52 & 1.01 & 0.21 & 0.45 & $\mu \mathrm{M}$ \\
\hline & Phosphate & 0.19 & 0.16 & 0.15 & 0.02 & $\mu \mathrm{M}$ \\
\hline & Silicate & 198 & 204 & 215 & 197 & $\mu \mathrm{M}$ \\
\hline & Chlorophyll-a & - & 0.62 & - & 0.55 & $\mu g \cdot L^{-1}$ \\
\hline \multirow[t]{9}{*}{ Sor } & Flow & 7.27 & 7.52 & 6.56 & 6.79 & $\mathrm{~m}^{3} \cdot \mathrm{s}^{-1}$ \\
\hline & Temperature & 18.3 & 19.1 & 19.7 & 20.3 & ${ }^{\circ} \mathrm{C}$ \\
\hline & Dissolved oxygen saturation & - & 98.0 & - & 98.0 & $\%$ \\
\hline & Nitrate & 38.1 & 32.2 & 39.3 & 35.3 & $\mu \mathrm{M}$ \\
\hline & Nitrite & 0.12 & 0.23 & 0.14 & 0.22 & $\mu \mathrm{M}$ \\
\hline & Ammonium & 0.33 & 0.58 & 0.22 & 1.18 & $\mu \mathrm{M}$ \\
\hline & Phosphate & 0.16 & 0.13 & 0.14 & 0.02 & $\mu \mathrm{M}$ \\
\hline & Silicate & 101 & 99 & 107 & 94 & $\mu \mathrm{M}$ \\
\hline & Chlorophyll-a & - & 0.41 & - & 0.45 & $\mu g \cdot L^{-1}$ \\
\hline \multirow[t]{9}{*}{ Landro } & Flow & 4.82 & 3.65 & 2.80 & 2.59 & $\mathrm{~m}^{3} \cdot \mathrm{s}^{-1}$ \\
\hline & Temperature & 16.2 & 17.3 & 16.1 & 18.8 & ${ }^{\circ} \mathrm{C}$ \\
\hline & Dissolved oxygen saturation & - & 96.6 & - & 94.9 & $\%$ \\
\hline & Nitrate & 43.1 & 41.0 & 41.3 & 49.2 & $\mu \mathrm{M}$ \\
\hline & Nitrite & 0.14 & 0.23 & 0.16 & 0.27 & $\mu \mathrm{M}$ \\
\hline & Ammonium & 0.28 & 4.00 & 0.57 & 1.42 & $\mu \mathrm{M}$ \\
\hline & Phosphate & 0.16 & 2.91 & 0.17 & 0.11 & $\mu \mathrm{M}$ \\
\hline & Silicate & 150 & - & 160 & 150 & $\mu \mathrm{M}$ \\
\hline & Chlorophyll-a & - & 0.92 & - & 0.64 & $\mu \mathrm{g} \cdot \mathrm{L}^{-1}$ \\
\hline
\end{tabular}


Table 2

Click here to download Table: Table_2.doc

Table 2. Mean abundance of phytoplankton and ciliates at station 5 in the Ria of 'O Barqueiro' in July and August 2008.

\begin{tabular}{|c|c|c|}
\hline PLANKTON GROUP & JULY & AUGUST \\
\hline \multicolumn{3}{|l|}{ PHYTOPLANKTON (cels $\cdot \mathrm{mL}^{-1}$ ) } \\
\hline \multicolumn{3}{|l|}{ (a) Dinoflagellate } \\
\hline Amphidinium flagellans & 1.88 & 0.37 \\
\hline Cochlodinium helix & 0.19 & 0.19 \\
\hline Gymnodinium spp. small & 1.50 & 0.00 \\
\hline Gyrodinium fusiforme & 0.21 & 0.00 \\
\hline Heterocapsa niei & 1.51 & 0.19 \\
\hline Karlodinium cf. micrum & 1.31 & 0.00 \\
\hline Lingulodinium polyedrum & 0.11 & 7.68 \\
\hline Prorocentrum minimum & 3.35 & 0.74 \\
\hline Protoperidinium steinii & 0.05 & 0.24 \\
\hline Total dinoflagellate & 11.12 & 10.14 \\
\hline \multicolumn{3}{|l|}{ (b) Diatoms } \\
\hline $\begin{array}{l}\text { Auxoesporas de Chaetoceros } \\
\text { spp. }\end{array}$ & 7.70 & 7.83 \\
\hline Amphora spp. & 0.76 & 0.00 \\
\hline Cerataulina pelagica & 0.19 & 0.37 \\
\hline Chaetoceros cf. convolutus & 0.21 & 1.69 \\
\hline Chaetoceros danicus & 0.19 & 0.37 \\
\hline Chaetoceros decipiens & 0.37 & 0.00 \\
\hline Chaetoceros gracilis & 0.37 & 0.76 \\
\hline Cocconeis spp. & 0.37 & 0.94 \\
\hline Grammatophora marina & 0.01 & 0.19 \\
\hline Guinardia delicatula & 3.34 & 0.01 \\
\hline Guinardia striata & 0.19 & 0.01 \\
\hline Gyrosigma spp. & 0.56 & 0.56 \\
\hline Leptocylindrus mediterraneus & 2.78 & 0.00 \\
\hline Leptocylindrus minimus & 4.28 & 1.48 \\
\hline Navicula distans & 0.20 & 0.05 \\
\hline Navicula spp. small & 0.37 & 5.57 \\
\hline Navicula transitans & 0.74 & 2.60 \\
\hline Nitzschia longissima & 1.52 & 4.82 \\
\hline Paralia sulcata & 0.10 & 3.34 \\
\hline $\begin{array}{l}\text { Pseudo-nitzschia cf. } \\
\text { delicatissima }\end{array}$ & 8.30 & 0.74 \\
\hline Pseudo-nitzschia spp. & 1.11 & 2.41 \\
\hline Proboscia alata & 0.19 & 0.20 \\
\hline Rhizosolenia imbricata & 2.04 & 2.78 \\
\hline Rhizosolenia setigera & 0.63 & 0.19 \\
\hline Thalassiosira nana & 2.27 & 2.64 \\
\hline Thalassiosira spp. & 2.41 & 2.23 \\
\hline Total diatoms & 42.32 & 42.01 \\
\hline \multicolumn{3}{|l|}{ (c) Flagellates } \\
\hline Flagellates 3-10 $\mu \mathrm{m}$ & 532.14 & 1120.46 \\
\hline \multicolumn{3}{|c|}{ (d) PLANKTONIC CILIATES (cels· $\mathrm{mL}^{-1}$ ) } \\
\hline Lohmaniella oviformis & 0.05 & 0.27 \\
\hline Myrionecta rubra & 0.00 & 0.31 \\
\hline Tontonia gracillima & 0.00 & 0.19 \\
\hline Strombidium acutum & 0.02 & 0.05 \\
\hline Leegardiella sol & 0.01 & 0.05 \\
\hline Srombidium epidemum & 0.00 & 0.04 \\
\hline Strombidium sp. & 0.01 & 0.02 \\
\hline Total ciliates & 0.14 & 1.07 \\
\hline
\end{tabular}


Table 3

Click here to download Table: Table_3.doc

Table 3.- Mean abundance of zooplankton at station 5 in the Ria of ' $O$ Barqueiro' in July and August 2008.

\begin{tabular}{|c|c|c|}
\hline \multirow{3}{*}{\multicolumn{3}{|c|}{$\begin{array}{l}\text { PLANKTON GROUP } \\
\text { ZOOPLANKTON (individuals } \cdot \mathrm{m}^{-3} \text { ) } \\
(\mathrm{e}) \text { Microzooplankton }(40-200 \mu \mathrm{m} \text { ) }\end{array}$}} \\
\hline & & \\
\hline & & \\
\hline \multicolumn{3}{|l|}{ Copepods } \\
\hline Nauplii larvae & 7295 & 3415 \\
\hline Calanoids & 68 & 49 \\
\hline Ciclopoids & 545 & 212 \\
\hline Harpacticoids & 34 & 0 \\
\hline \multicolumn{3}{|l|}{ Larvae } \\
\hline Bivalves & 2523 & 1536 \\
\hline Gasteropods & 1023 & 392 \\
\hline \multicolumn{3}{|l|}{ Tintinnids } \\
\hline Eutintinnus sp. & 102 & 16 \\
\hline Rhabdonella elegans & 102 & 654 \\
\hline Favella spp. & 0 & 114 \\
\hline \multicolumn{3}{|l|}{ Other groups } \\
\hline Apendicularia & 136 & 49 \\
\hline Total microzooplankton & 11898 & 6438 \\
\hline \multicolumn{3}{|l|}{ (f) Mesozooplankton $(>200 \mu \mathrm{m})$} \\
\hline Apendicularia & 749 & 501 \\
\hline \multicolumn{3}{|l|}{ Cladocerans } \\
\hline Evadne nordmanni & 7 & \\
\hline Evadne spinifera & 0 & 354 \\
\hline Podon intermedius & 72 & 23 \\
\hline \multicolumn{3}{|l|}{ Copepods } \\
\hline Acartia clausi & 736 & 19 \\
\hline Acartia juveniles & 768 & 60 \\
\hline Calanus juveniles & 33 & 8 \\
\hline Centropages chierchiae & 65 & 49 \\
\hline Centropages juveniles & 788 & 45 \\
\hline Clausocalanus spp. & 0 & 30 \\
\hline Copepodits & 1902 & 320 \\
\hline Ditrichocorycaeus anglicus & 0 & 11 \\
\hline Euterpina acutifrons & 0 & 15 \\
\hline Isias clavipes & 163 & 8 \\
\hline Nauplii larvae & 39 & 11 \\
\hline Oithona nana & 13 & 0 \\
\hline Oithona similis & 169 & 222 \\
\hline Oncaea media & 13 & 72 \\
\hline Paracalanus parvus & 931 & 494 \\
\hline Parapontella brevicornis & 26 & 0 \\
\hline Gastropods larvae & 319 & 260 \\
\hline \multicolumn{3}{|l|}{ Crustacean larvae } \\
\hline Braquiura zoea & 20 & 4 \\
\hline Cirripods cypris & 46 & 8 \\
\hline Cirripods nauplii & 189 & 313 \\
\hline Decapods & 26 & 4 \\
\hline Euphausacians & 0 & 11 \\
\hline Bivalves larvae & 46 & 369 \\
\hline Echinoderms larvae & 0 & 23 \\
\hline Fish larvae & 7 & 11 \\
\hline Sifonofora & 0 & 19 \\
\hline Total copepods & 5646 & 1364 \\
\hline Total mesozooplankton & 7131 & 3289 \\
\hline
\end{tabular}


Figure 1

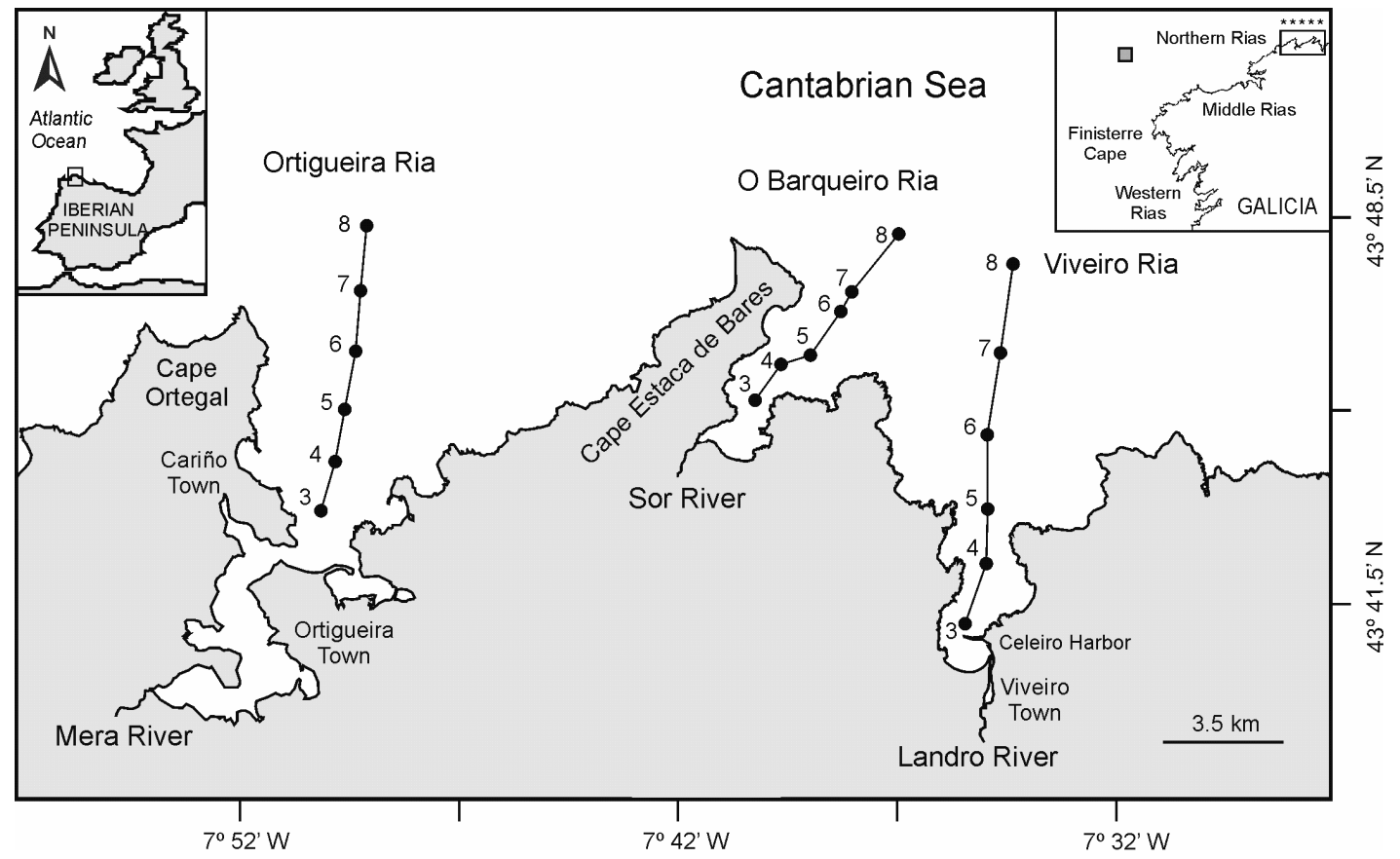

Figure 1 
Figure 2

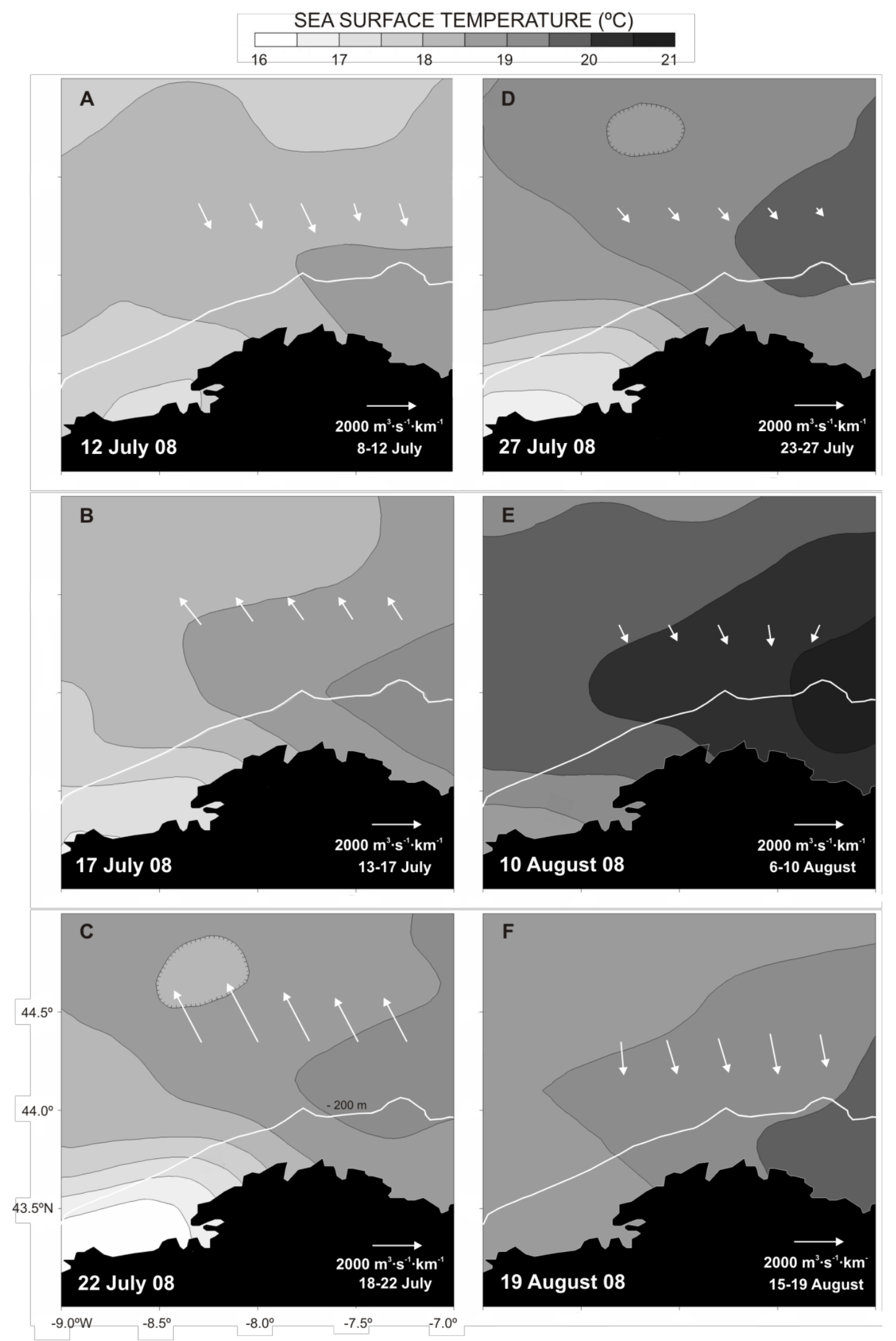

Figure 2 
Figure 3

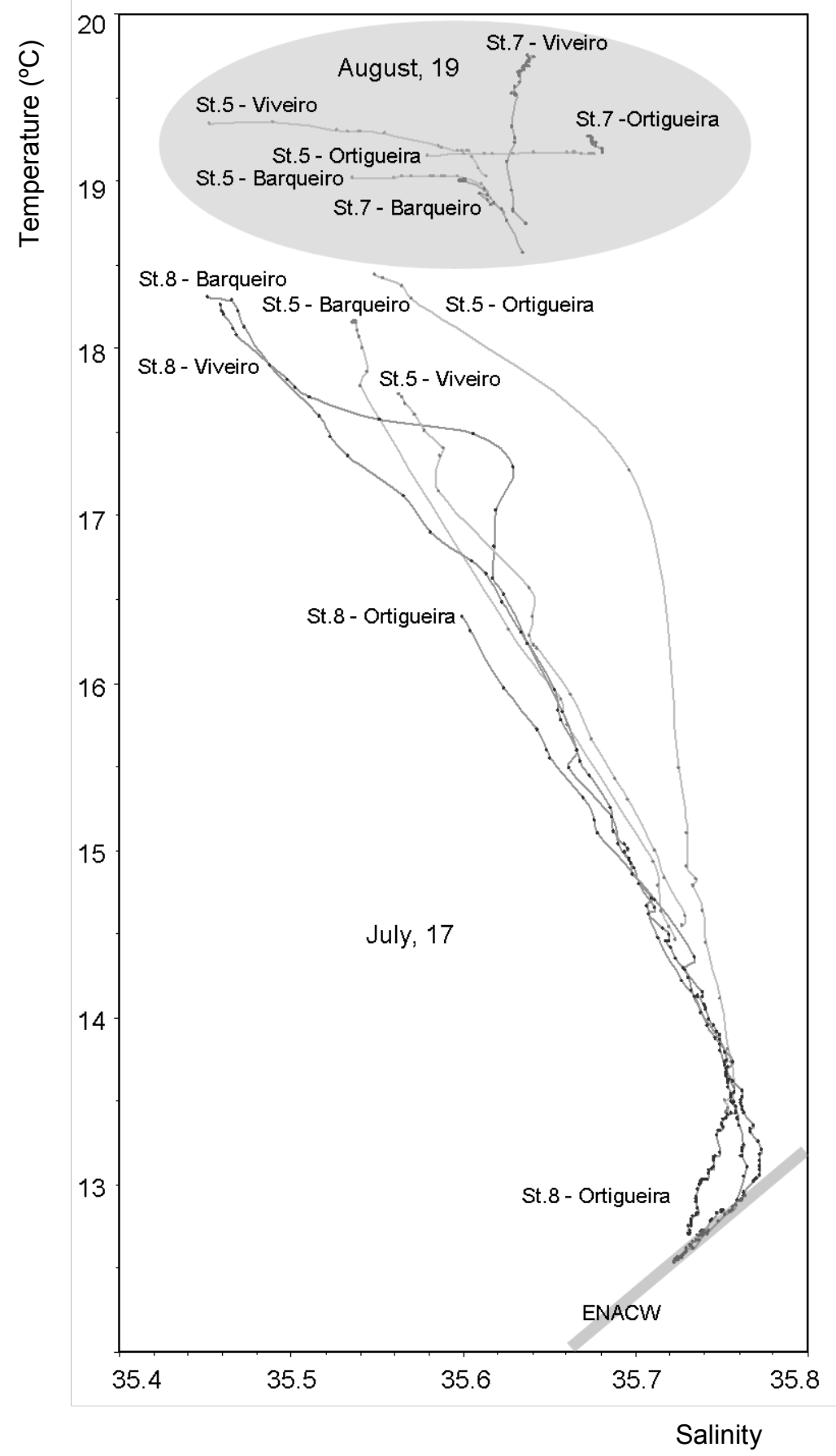

Figure 3 
Figure 4

A
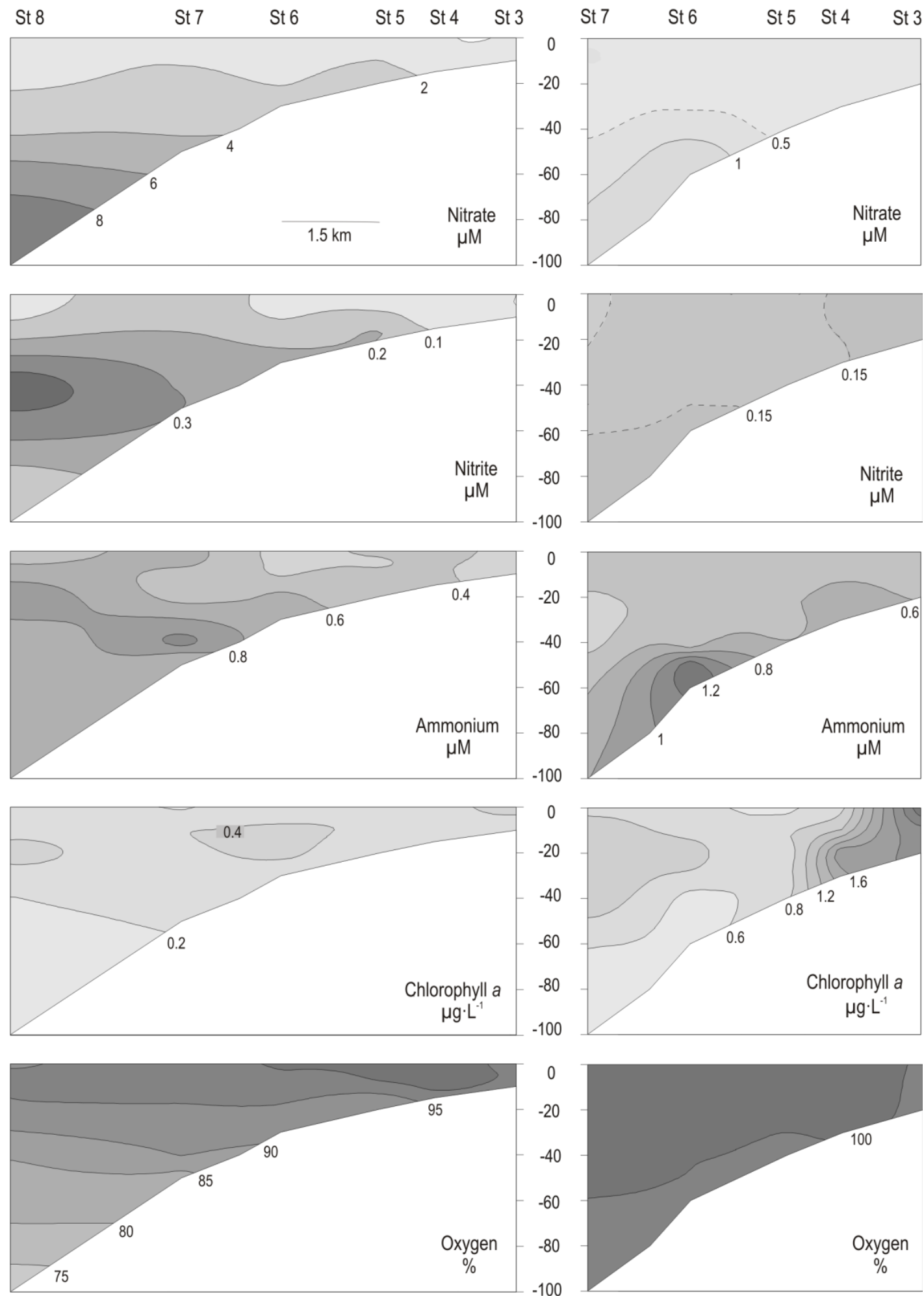

July - (O Barqueiro Ria)

Depth (m) August - (O Barqueiro Ria) 
B
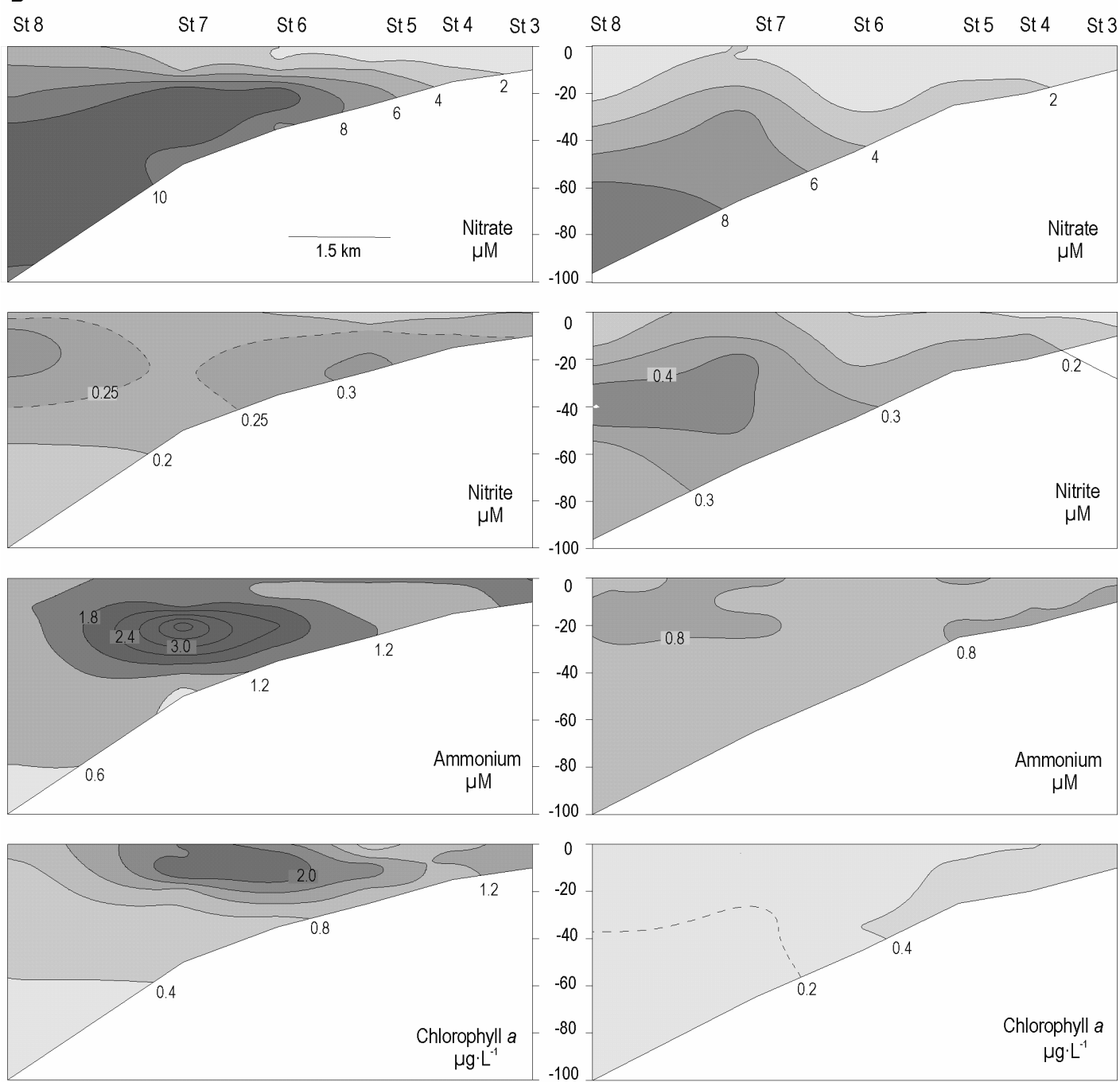

July - (Ortigueira Ria)

Depth (m)

July - (Viveiro Ria)

Figure 4 
Figure 5

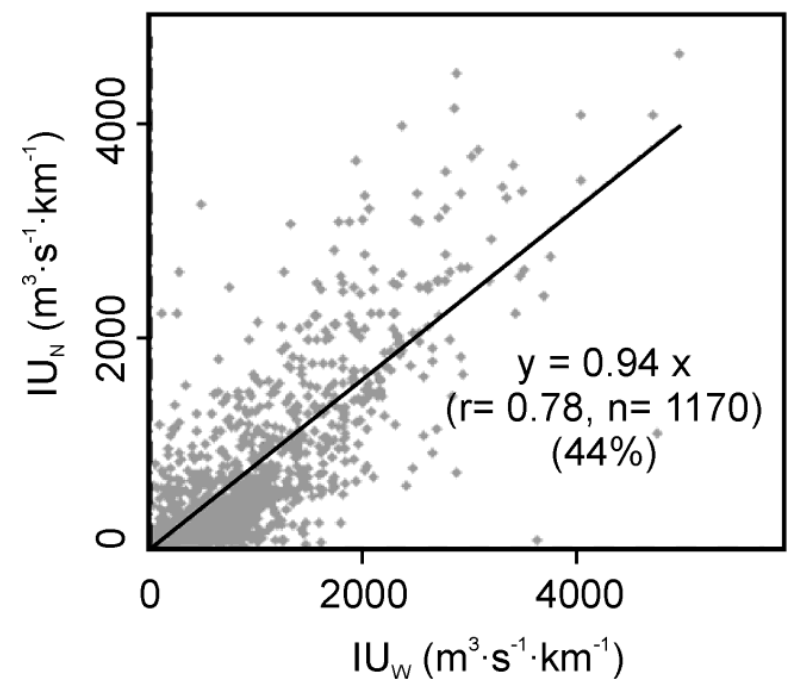

Figure 5 